\title{
EFFECT OF COMPONENT COMPOSITION OF PIGMENT COMPLEX ON THE FORMATION OF COLOR OF RHUBARB AND GOOSEBERRY
}

\author{
Antonina Dubinina \\ Department of Merchandising and Goods' Examination \\ Kharkiv State University of Food Technology and Trade \\ 333 Klochkivska str., Kharkiv, Ukraine, 61051 \\ tovaroved206@ukr.net \\ Galina Selyutina \\ Department of Merchandising and Goods' Examination \\ Kharkiv State University of Food Technology and Trade \\ 333 Klochkivska str., Kharkiv, Ukraine, 61051

\section{Tetiana Letuta} \\ Department of Merchandising and Goods' Examination \\ Kharkiv State University of Food Technology and Trade \\ 333 Klochkivska str., Kharkiv, Ukraine, 61051

\section{Tetiana Shcherbakova} \\ Department of Merchandising and Goods' Examination \\ Kharkiv State University of Food Technology and Trade \\ 333 Klochkivska str., Kharkiv, Ukraine, 61051 \\ Vita Afanasieva \\ Department of Marketing and Trade Entrepreneurship \\ Kharkiv Trade and Economic Institute of Kyiv National Trade and Economic University \\ 8 O. Yarosha lane, Kharkiv, Ukraine, 61045 \\ vitaaf@ukr.net
}

\footnotetext{
Abstract

The objective of present study is to determine the influence of component composition of pigment complex on the formation of color of rhubarb and gooseberry that defines consumer properties of these plant products. We report comparative study of rhubarb of the botanical varieties Monarch, Linney, Krupnochereshkovyy, Ogrski, and of gooseberry of the varieties Malachite, Pavlovsky green, Green urozhainyy, Green butylochnyy, zoned in the eastern regions of Ukraine. To determine the content of pigment complex substances of rhubarb and gooseberry, we used methodology by V. F. Gavrilenko and L. M. Khandobina. The method of the International Commission on Illumination (ICI) was applied for quantitative characteristic of color.

Results of research into qualitative and quantitative composition of pigment complex of berries of gooseberry and rhubarb stalks revealed that the main components are the chlorophylls whose overall content for different varieties of rhubarb is $(3.7 \ldots 4.5) \cdot 10^{-3} \%$, for berries of gooseberry is $(3.5 \ldots 4.7) \cdot 10^{-3} \%$. The color characteristics of the examined samples of gooseberry and rhubarb are correlated with the quantitative content of pigments in the raw materials and make it possible to determine the dominant tone $\left(\lambda_{\mathrm{d}}, \mathrm{nm}\right)$ - green, color purity - green with shades of blue, brightness - green, light green, dark green, which coincide with the visual estimation of color.

We show expediency of the application of the ICI XYZ method to characterize the color, which considerably facilitates the estimation of color when assessing the quality of food products.
}

Keywords: dominant wavelength, color purity, brightness, the International Commission on Illumination method.

DOI: 10.21303/2504-5695.2017.00506 C Antonina Dubinina, Galina Selyutina, Tetiana Letuta, Tetiana Shcherbakova, Vita Afanasieva

\section{Introduction}

Among the chlorophyll-containing fruits and vegetables that grow in Ukraine and which are used for processing in order to extend assortment of food products rich in natural 
functional ingredients (chlorophylls, carotenoids, vitamins, mineral elements, dietary fibers), quite common are rhubarb and gooseberry. They are characterized by early ripening times and high annual yield. Products from rhubarb and berries of gooseberry are distinguished by high consumer properties and are in great demand among the population $[1,2]$. At the same time, thermal treatment leads to the deterioration of physical appearance, especially color, compared with the raw materials. In this case, natural green color transforms into yellow or yellow-brown $[3,4]$.

It should be noted that the papers on the processing of rhubarb and gooseberry $[1,2,5-7]$ fail to adequately address issues related to the pigment complex and its relationship with varietal differences, as well as to questions of maximal preservation of these components; not enough attention is paid to chromaticity problems.

In some cases, color becomes a decisive indicator of quality, which, in line with the requirements of the standard or other normative documentation, defines the technical advantages of the examined product. Such a relationship between quality and color is especially pronounced for the products of plant origin since this is predetermined by a close correlation between the color and the degree of ripeness of fresh fruits and vegetables. Most often, coloration is regulated as the attribute representative of a given vegetable variety or the property typical for a given fruit. A specific color is rarely specified, for example, red, pink for tomato; red-violet, blue-red for red cabbage.

The coloration of raw plant materials is predetermined by the presence of natural dyes chlorophylls, carotenoids and flavonoids. The first two relate to lipoids because they are insoluble in water, but only in fats and organic solvents. Flavonoids belong to water-soluble substances. This classification is based on the properties of these compounds and is rather widely applied. The data accumulated up to now indicate that chlorophyll not only exerts the effect of its color on consumer properties of food products, but also improves nutritional value [3, 8].

The objective of present study is to determine the impact of component composition of pigment complex on the formation of the color of rhubarb and gooseberry, which characterizes consumer properties of these plant products.

\section{Materials and Methods}

We selected, for conducting the experiment, the berries of gooseberry of the varieties Malachite, Pavlovsky green, Green urozhainyy, Green butylochnyy, and the stalks of rhubarb of the varieties Monarch, Linney, Krupnochereshkovyy, Ogrski, from the Institute of Vegetable and Melon Cultivation of the Ukrainian Academy of Agrarian Sciences, the city of Merefa, Kharkiv oblast (Fig. 1, 2).

We used methodology by V.F. Gavrilenko and L.M. Khandobina to determine the content of pigment complex substances for rhubarb and gooseberry [9]. According to this method, a batch of fresh plant material $(0.3 \ldots 0.5 \mathrm{~g})$ is thoroughly ground in a porcelain mortar with a small amount of organic solvent $\left(2 \ldots 3 \mathrm{~cm}^{3}\right)$, pure quartz sand and magnesium carbonate. After holding for $(2 \ldots 3) \mathrm{min}$, the extract is taken on a glass filter and is filtered into a Bunsen flask using a waterjet pump. The extraction of pigments with small portions of pure solvent is repeated on the filter 3...4 times till full removal of the pigments. The last portions of the filtrate must be colorless. The extracts are quantitatively taken to a measuring flask of $50 \mathrm{~cm}^{3}$; the volume of the extraction is brought by pure organic solvent to the mark. The obtained extraction contains the sum of green and yellow pigments of the plant raw material.

Using the spectrophotometer SF-103 (NPKF Aquilon, Russia) (Fig. 3), we determined the intensity of light absorption by the resulting extraction of pigments at wavelengths corresponding to the maxima of absorption of pigments in a given solvent $-662 \mathrm{~nm}, 644 \mathrm{~nm}, 440.5 \mathrm{~nm}$. Pigment concentration was calculated from formulae [10].

We used the International Commission on Illumination (ICI) method to quantitatively characterize the color [11]. The purpose of the method is determining the process for measuring and estimating color characteristics (Fig. 3). 


\section{Reports on research}

projects
(2017), «EUREKA: Life Sciences»

Number 6

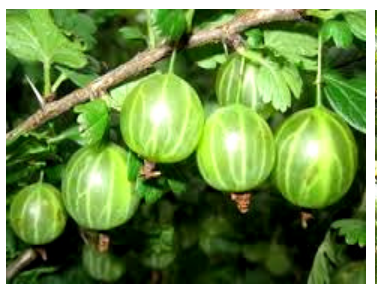

$a$

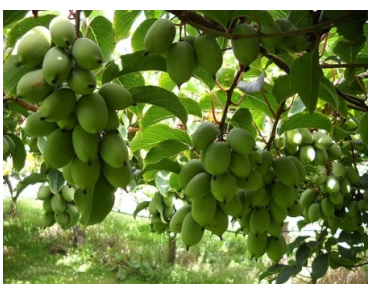

$b$

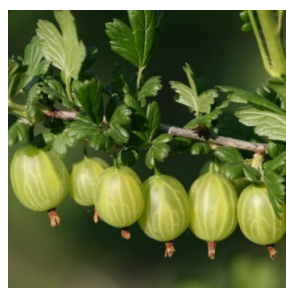

$c$

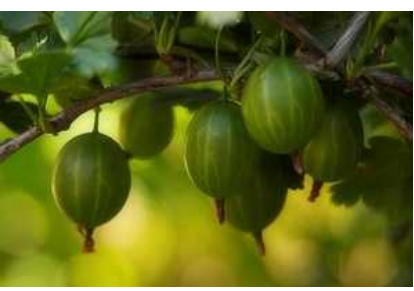

$d$

Fig. 1. Gooseberry of the varieties: (a) Malachite; (b) Pavlovsky green;

(c) Green urozhainyy; (d) Green butylochnyy

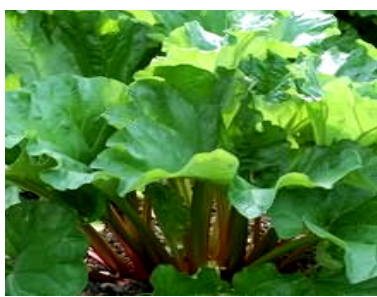

$a$

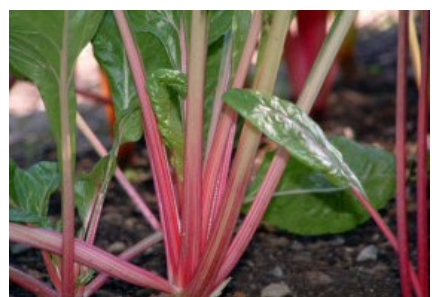

$b$

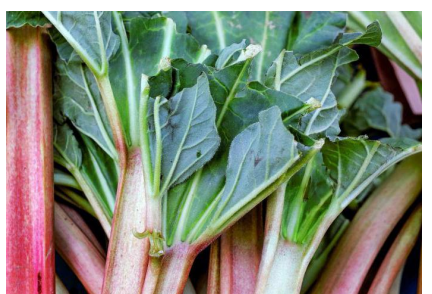

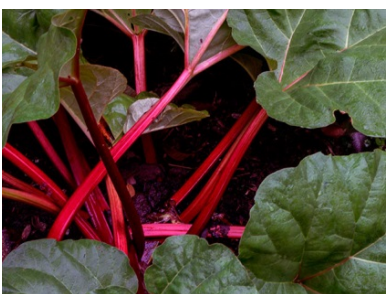

$d$

Fig. 2. Rhubarb of the varieties: (a) Monarch; (b) Linney; (c) Krupnochereshkovyy; $(d)$ Ogrski

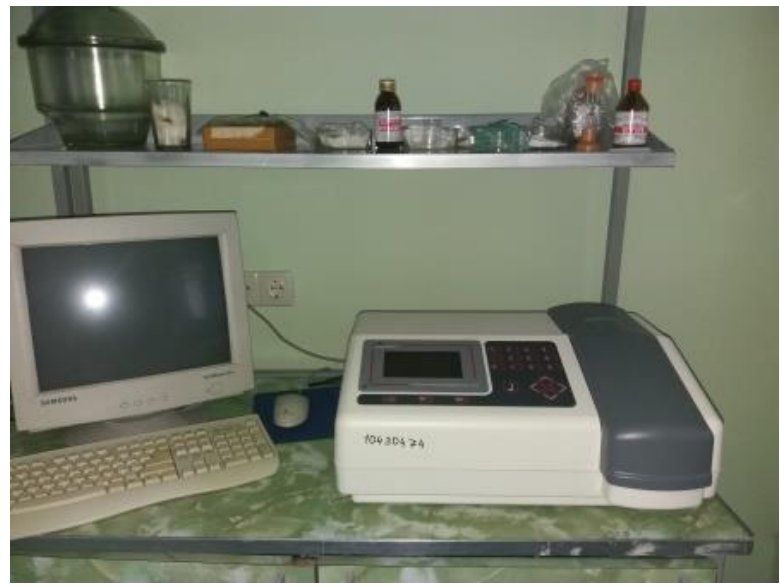

Fig. 3. Spectrophotometer SF-103

This model is the closest to the perception of an actual observer. We measured spectra of the diffuse reflection of experimental samples using the spectrophotometer Techkon SP-810 (Techkon, Germany) in the range of $400 \ldots 700 \mathrm{~nm}$ in a step of $10 \mathrm{~nm}$ and the number of cycles of accumulation of 20 (Fig. 4).

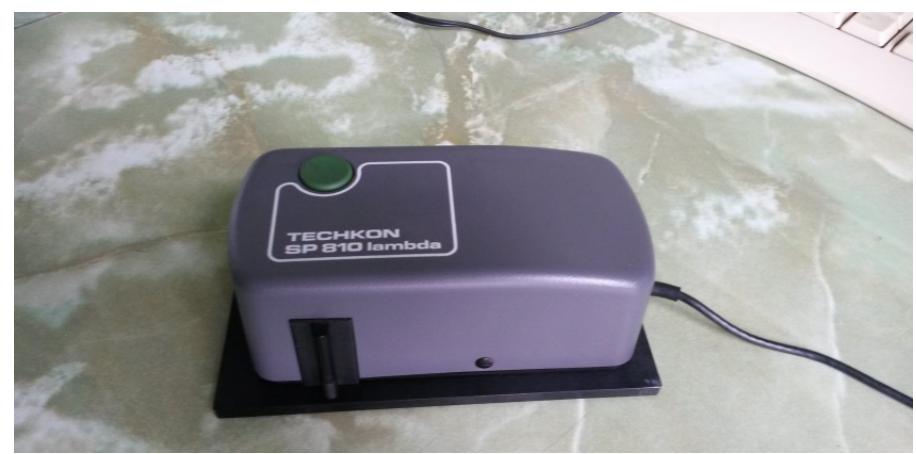

Fig. 4. Spectrophotometer Techkon SP-810 
Using the embedded software SFScan, we determined integral color coordinates X, Y, Z, conditionally expressed in relative units of the ICE system; they are dimensionless. Applying the obtained coordinates of color, we estimated specific coordinates $(\mathrm{x}, \mathrm{y})$, which enable determining of the following parameters - purity of the color $(\mathrm{P}, \%)$, brightness $(\mathrm{T}, \%)$, dominant wavelength $\left(\lambda_{\mathrm{d}}, \mathrm{nm}\right)$.

Experiments were repeated five times in the course of research. Statistical processing of research results was carried out using a correlation-regression analysis. Experimental data were processed by the method of Fisher-Student at confidence level of 0.95 . Results of the experiment were processed in the environment Microsoft Excel of the MathCad software package.

\section{Experimental procedures. Exploring the composition of pigments and the color of rhubarb and gooseberry depending on the type of botanical and pomological varieties}

We conducted comparative study of the botanical varieties of rhubarb, which are zoned in the eastern regions of Ukraine. To that end, we obtained extracts that contained coloring substances, from the stalks of rhubarb of the varieties Monarch, Linney, Krupnochereshkovyy, Ogrski, and acquired absorption spectra that characterize the presence of chlorophylls. Basic substances of the pigment complex of the examined varieties of rhubarb are given in Table $\mathbf{1}$.

Table 1

Basic components of the pigment complex of rhubarb

\begin{tabular}{ccccc}
\hline \multirow{2}{*}{ Content of pigment complex substances, $\mathbf{1 0}^{-\mathbf{3}} \mathbf{\%}$} & \multicolumn{3}{c}{ Botanical varieties of rhubarb } \\
& Krupnochereshkovyy & Linney & Monarch & Ogrski \\
\hline Chlorophylls: & $3.8 \pm 0.3$ & $4.1 \pm 0.3$ & $4.5 \pm 0.4$ & $3.7 \pm 0.3$ \\
chlorophyll $a$ & $2.7 \pm 0.2$ & $2.9 \pm 0.2$ & $3.3 \pm 0.3$ & $2.7 \pm 0.2$ \\
chlorophyll $b$ & $1.08 \pm 0.09$ & $1.17 \pm 0.09$ & $1.3 \pm 0.1$ & $1.08 \pm 0.9$
\end{tabular}

An analysis of the obtained results showed that the main pigments that determine green coloration of rhubarb samples are the chlorophylls. Their total content is within (3.7...4.5) $10^{-3} \%$; in this case, the content of blue-green chlorophyll $a$ is larger in the stalks of rhubarb of the variety Monarch $-3.3 \cdot 10^{-3} \%$, which are distinguished by dark green color, the lowest content of this pigment is in rhubarb of the variety Ogrski, $2.7 \cdot 10^{-3} \%$.

Similar study was carried out for different varieties of gooseberry. Characteristic of the pigment complex of berries of gooseberry for different pomological varieties is given in Table 2 .

Table 2

Comparative characteristic of the pigment complex of berries of gooseberry for different pomological varieties

\begin{tabular}{ccccc}
\hline Content of pigment complex substances, $\mathbf{1 0}^{-\mathbf{3}} \mathbf{\%}$ & \multicolumn{3}{c}{ Pomological varieties of gooseberry } \\
& Green butylochnyy & Green urozhainyy & Pavlovsky green & Malachite \\
\hline Chlorophylls: & $4.3 \pm 0.3$ & $3.5 \pm 0.3$ & $3.6 \pm 0.3$ & $3.9 \pm 0.3$ \\
chlorophyll $a$ & $3.1 \pm 0.3$ & $2.5 \pm 0.2$ & $2.6 \pm 0.2$ & $2.8 \pm 0.2$ \\
chlorophyll $b$ & $1.2 \pm 0.1$ & $1.04 \pm 0.08$ & $1.05 \pm 0.08$ & $1.11 \pm 0.09$
\end{tabular}

As evidenced by the obtained data (Table 2), basic components of the chlorophyll complex of berries of gooseberry for different varieties are the chlorophylls $a$ and $b$ : their content in different varieties of gooseberry ranges within $(3.5 \ldots 4.3) \cdot 10^{-3} \%$. It should be noted that the minimum content of chlorophyll $a$ was found in berries of the variety Green urozhainyy $-2.49 \cdot 10^{-3} \%$; the maximum content is in the variety Green butylochnyy $-3.1 \cdot 10^{-3} \%$. These very pigments mainly determine green coloration of the berries of gooseberry. 


\section{Results}

The color of the examined samples is determined mainly by the presence of such colorants such as chlorophyll $a$ and chlorophyll $b$. Other components do not significantly affect the coloring of stalks since their content is considerably less in comparison with the amount of chlorophyll.

The content of chlorophyll $(a+b)$ makes it possible to characterize the nutritional value of the product, but does not make it possible to fully assess its color, which is an important indicator of commercial estimation of food quality. In order to obtain a more objective assessment, we determined spectral reflection coefficients $R_{f}$ for different varieties of rhubarb in the visible wavelength range $400 \ldots 700 \mathrm{~nm}$, which allowed us to establish characteristics of color in a three-color ICI XYZ coordinate system. Reflection spectra are shown in Fig. 5 for all botanical varieties of rhubarb (Fig. 5).

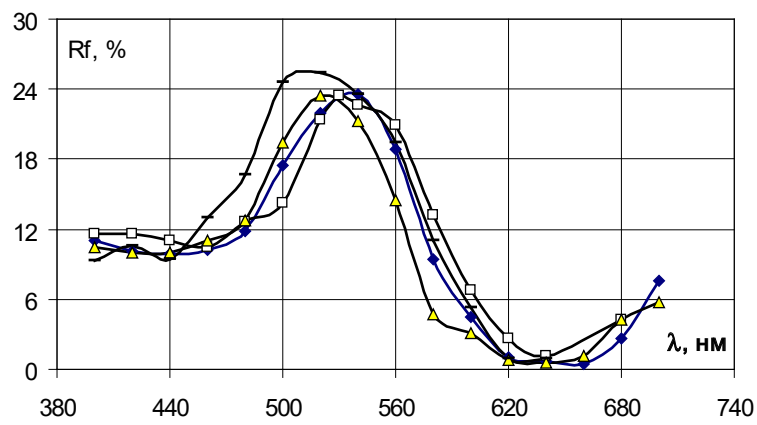

Fig. 5. Reflection spectra of rhubarb samples: (1) variety Ogrski, (2) variety Linney,

(3) variety Krupnochereshkovyy, (4) variety Monarch

In a given method, color is characterized by such parameters as brightness, color purity (of the basic tone), dominant wavelength (dominating tone) (Table 3). The dominant wavelength $\left(\lambda_{\mathrm{d}}, \mathrm{nm}\right)$ for all samples is in the range $495 \ldots 511 \mathrm{~nm}$, that is, in the green spectral region of visible light. Brightness (R) varies from $40.7 \%$ for rhubarb of the variety Monarch, to $52.6 \%$ for rhubarb of the variety Ogrski. Color purity of the sample of rhubarb of the variety Monarch, which is characterized by darker stalks, is $52.25 \%$. For other samples, $49.37 . .52 .60 \%$. Organoleptic evaluation of the color of all samples of rhubarb, conducted in line with the standard, allows us to characterize it as green of different intensity [12].

Table 3

Color characteristics of rhubarb samples $(\mathrm{Sr}=0.05, \mathrm{n}=5, \mathrm{p}=0.95)$

\begin{tabular}{ccccc}
\hline Botanical varieties & $\begin{array}{c}\text { Dominant wavelength } \\
\boldsymbol{\lambda}_{\mathbf{d}}, \mathbf{n m}\end{array}$ & $\begin{array}{c}\text { Brightness } \\
\mathbf{T ,} \mathbf{\%}\end{array}$ & $\begin{array}{c}\text { Color purity } \\
\mathbf{P}, \mathbf{\%}\end{array}$ & $\begin{array}{c}\text { Visual assessment of } \\
\text { samples' color }\end{array}$ \\
\hline Krupnochereshkovyy & 508.9 & 50.6 & 50.23 & green \\
Linney & 510.5 & 51.7 & 49.37 & green \\
Monarch & 494.7 & 40.7 & 52.25 & saturated green \\
Ogrski & 510.7 & 52.6 & 52.60 & light green
\end{tabular}

Similarly, we acquired spectral reflection coefficients $\mathrm{R}_{\mathrm{f}}$ for the samples of different varieties of gooseberry in the specified range. The calculated color parameters are given in Table 4.

Color purity of the sample of gooseberry of the variety Green butylochnyy whose berries are characterized by dark green color is $47.09 \%$. For other samples, color purity is from $47.7 \%$ to $52.6 \%$. Minimum brightness is demonstrated by gooseberry of the variety Green butylochnyy $-38.8 \%$; for other samples, it is $50 . .53 .6 \%$. Organoleptic evaluation of the color of all samples of gooseberry also allows us to characterize it as green of different intensity. 
Table 4

Color characteristics of the examined samples of gooseberry $(\mathrm{Sr}=0.05, \mathrm{n}=5, \mathrm{p}=0.95)$

\begin{tabular}{|c|c|c|c|c|}
\hline Pomological varieties & $\begin{array}{l}\text { Dominant wavelength } \\
\qquad \lambda_{d}, \mathbf{n m}\end{array}$ & $\begin{array}{c}\text { Brightness } \\
\text { T, \% }\end{array}$ & $\begin{array}{c}\text { Color purity } \\
\text { P, \% }\end{array}$ & $\begin{array}{l}\text { Visual assessment of } \\
\text { samples' color }\end{array}$ \\
\hline Green butylochnyy & 493.2 & 38.8 & 47.09 & dark green \\
\hline Green urozhainyy & 511.6 & 52.6 & 50.04 & green \\
\hline Pavlovsky green & 510.3 & 51.0 & 47.70 & green \\
\hline Malachite & 511.8 & 53.6 & 52.59 & green \\
\hline
\end{tabular}

The results of pigment content in rhubarb and gooseberry make it possible to evaluate their biological significance, as well as select required technological operations for maximum preservation of biologically active substances and natural coloration of raw materials. The obtained color characteristics allow us to predict, with a high probability, the character of changes of pigments during technological processing of raw materials and their quantitative composition. Since the reflection spectra measurement does not require lengthy preparation of samples, the color characterization by color indicators can be considered an express-method, which considerably facilitates the work of specialists when selecting technological operations during processing of fruits and vegetables in order to preserve their quality.

\section{Conclusions}

1. Results of research into qualitative and quantitative composition of pigment complex of gooseberry and rhubarb stalks showed that the main components are the chlorophylls whose overall content for different varieties of rhubarb is $(3.7 . .4 .5) \cdot 10^{-3} \%$, for berries of gooseberry - $(3.5 \ldots 4.7) \cdot 10^{-3} \%$.

2 . The color characteristics of the examined samples of gooseberry and rhubarb correlate to the quantitative content of pigments in the raw materials and make it possible to determine the dominant tone $\left(\lambda_{\mathrm{d}}, \mathrm{nm}\right)$, which is green; color purity, which is green with shades of blue; brightness, which is light green, dark green, which coincide with the visual assessment of color.

An important criterion of quality is the color, which for food, in most cases, is determined in accordance with the organoleptic standard, in other words, by a subjective method. Modern consumer requirements to quality and safe products necessitates the use of new and the improvement of existing methods for evaluating color.

The obtained characteristics are in good agreement with the visual assessment of color, which is why the specified spectral method could be employed in future when selecting formulation components, selecting the conditions for technological processing of fruits and vegetables, which would significantly facilitate the work of specialists.

\section{References}

[1] Koveshnikova, E. Yu., Merkulova, M. I. (1999). Kryzhovnik kak syr'e dlya tekhnologicheskoy pererabotki. Sadovodstvo i vinogradarstvo, 1, 11-13.

[2] Rybalov, L. I., Gievkovskaya, M. G. (1982). Izuchenie sortov kryzhovnika na yuge Ukrainy. Konserv. i ovoshchesush. prom-t', 4, 22-23.

[3] Merzlyak, M. N. (1998). Pigmenty, optika lista i sostoyanie rasteniy. Sorosovskiy obrazovatel'nyy zhurnal: Seriya Biologiya, 4, 19-24.

[4] Schwartz, S. J., Lorenzo, T. V. (1990). Chlorophylls in foods. Critical Reviews in Food Science and Nutrition, 29 (1), 1-17. doi: 10.1080/10408399009527511

[5] Sovremennye tekhnologii khraneniya i pererabotki plodoovoshchnoy produktsii (2009). Moscow: FGNU «Rosinformagrotekh», 172.

[6] Deynichenko, G. V., Dubinina, A. A., Selyutina, G. A. (2000). Reven' i kryzhovnik: novye polufabrikaty. Pitanie i obshchestvo, 10, 23-24. 
[7] Seliutina, H. A. (2000). Vplyv deiakykh faktoriv na zberezhennia khlorofiliv pid chas pererobky. Part 1. Prohresyvni tekhnolohii ta udoskonalennia protsesiv kharchovykh vyrobnytstv, 244-248.

[8] Ermakov, V. A. (1986). Biokhimicheskie metody issledovaniya. Moscow: Nauka, 355.

[9] Pochinok, H. N. (1976). Methods of plants' biochemical analysis. Kyiv: Scientific Thought, 334.

[10] Dzhadd, D., Vyshetski, G. (1978). Svet v nauke i tekhnike. Moscow: Mir, 690.

[11] Reven' svezhiy: PCT URSR 299-89 [Vzamen RST USSR 299-80] (1989). Kyiv: Gosplan USSR, 6.

\title{
RESEARCH INTO TECHNOLOGICAL INDICATORS OF A RYE-WHEAT DOUGH SEMI-FINISHED PRODUCT WITH THE ADDITION OF THE POLYFUNCTIONAL FOOD SUPPLEMENT "MAGNETOFOOD"
}

\author{
Iryna Tsykhanovska \\ Department of food and chemical technologies \\ Ukrainian Engineering-Pedagogics Academy \\ 16 Universitetska str., Kharkiv, Ukraine, 61003 \\ cikhanovskaja@rambler.ru \\ Victoria Evlash \\ Department of Chemistry, Microbiology and Food Hygiene \\ Kharkiv State University of Nutrition and Trade \\ 333 Klochkivska str., Kharkiv, Ukraine, 61051 \\ evlashvv@gmail.com \\ Alexandr Alexandrov \\ Department of food and chemical technologies \\ Ukrainian Engineering-Pedagogics Academy \\ 16 Universitetska str., Kharkiv, Ukraine, 61003 \\ alexandrov.a.v.a.v@gmail.com \\ Tetiana Lazareva \\ Department of food and chemical technologies \\ Ukrainian Engineering-Pedagogics Academy \\ 16 Universitetska str., Kharkiv, Ukraine, 61003 \\ Lazareva_T.A@ukr.net \\ Karina Svidlo \\ Department of Technology and Restaurant Business Organization \\ Kharkiv Trade and Economic Institute of Kiev National Trade and Economic University of Ukraine \\ 8 O. Yarosha lane, Kharkiv, Ukraine, 61045 \\ karinasvidlo@rambler.ru

\section{Tatyana Gontar} \\ Department of food and chemical technologies \\ Ukrainian Engineering-Pedagogics Academy \\ 16 Universitetska str., Kharkiv, Ukraine, 61003 \\ taty-gontar@ukr.net
}

Abstract

We studied influence of the polyfunctional food supplement "Magnetofood" on the technological parameters of rye-wheat dough semi-finished product and the finished product. A positive effect of the supplement "Magnetofood" on the technological 